\title{
Moral Virtues in J. A. Comenius’ Mundus Moralis
}

\author{
Kateřina Šolcová
}

\begin{abstract}
The aim of the article is to reconstruct Jan Amos Comenius' (1592-1670) conception of moral virtues as it is presented in his major work General Consultation on an Improvement of All Things Human (De rerum humanarum emendatione consultatio catholica), mainly in its part Pansophia - Mundus Moralis with respect to the role which prudence plays (prudentia) in relation to the other cardinal virtues - fortitude (fortitude), justice (justitia), and temperance (temperantia). Comenius' conception of virtues is further compared with the traditional Aristotelian-Scholastic doctrine formulated prevailingly by Aquinas. In conclusion, it is shown that it is the position of prudence (prudentia), as an intellectual virtue that connects significantly Comenius with the Aristotle-Thomistic tradition in this perspective.
\end{abstract}

Keywords: Comenius, moral virtues, cardinal virtues, prudence, Aristotle, Aquinas

\section{Introduction}

The quality of the human personality was an important topic that has attracted attention since the ancient history of mankind. One can think of the mythological figures of gods and heroes, whose properties have been praised or vilified. Moral qualities occupy a special position here, as the qualities that give direction to human behaviour. These properties, when they are morally positive, are called virtues, ${ }^{1}$ morally negative ones are vices. Virtues that were of fundamental importance to human behaviour, over time, came to be called cardinal virtues, ${ }^{2}$ those around which human life spins like a door in their door jambs (cardo) (Aquinas, 2013, p. 34).

The cardinal virtues are four: justice (justitia) - traditionally perceived as a virtue to give everyone his or her rights (Comenius, 1966b, p. 566), ${ }^{3}$ fortitude (fortitudo) - the strength to face difficulties, in particular the danger of death (Comenius, 1966b, p. 536), ${ }^{4}$ temperance (temperantia) - the right level in the pursuit of sensual pleasure (Comenius, 1966b, p. 662). ${ }^{5}$ A special role in this foursome is taken by prudence (prudentia) - the correct judgment regarding human behaviour (Comenius, 1966a, p. 624) ${ }^{6}$ according to which a prudent person decides on the appropriate course of his or her actions. As prudence directly controls judgment and conscience underlying every other virtue, it becomes a kind of conductor who manages the other virtues. Additionally, prudence can be understood as a light, which makes practical reason discern the true good in every situation and choose the appropriate means to achieve it. Consequently, other virtues are derived from cardinal virtues, as parts of them (partes subjectivae, integrantes, potentiales), aside from the obviously divine virtues (Hope, Love, and Faith) that have an entirely different position.

\footnotetext{
${ }^{1}$ It should be noted that the ancients understood the meaning of the word virtue areté more widely, as a prowess that originally was not confined to the field of the moral. Aristotle, in the Nicomachean Ethics systematically distinguished intellectual and moral virtues.

${ }^{2}$ The term cardinal virtues (virtutes cardinales) was first used by Saint Ambrose in his Expositio evangelii secundum Lucam [Commentary on the Gospel according to Luke].

${ }^{3}$ Justitia est virtus suum cuique tribuens. Vel, est ad juris leges vivendi studium.

${ }^{4}$ Fortitudo est ad ea, quae difficultatibus terrent, sive in agendo, sive in patiendo robur.

${ }^{5}$ Temperantia est cupiditatum et actionum moderatio, ut ne quid nimis.

${ }^{6}$ Prudentia est ars tranquilitati suae et aliorum providendi, per media certa, mediisque utendi modos debitos.
} 
The theme of virtues has become an important part of Christian ethics and it would be certainly interesting to watch its development through centuries and cultures. In our context, however, it is important that among the many thinkers who paid attention to virtues was Jan Amos Comenius (1592-1670). In this text I intend to focus on the concept of virtues, particularly prudence, as contained in the $6^{\text {th }}$ grade of Pansophy entitled Mundus moralis Moral World which is part of Comenius's work De rerum humanarum emendatione consultatio catholica - General Consultation on the Reform of All Things Human. His views are consequently compared with the traditional Aristotelian conception which was further processed primarily by Thomas Aquinas, but also by other Christian theologians. Finally, I will argue that it is the position of prudence (prudentia), as the intellectual virtue that significantly connects both systems.

\section{Comenius's Mundus Moralis}

It should be noted that although Comenius in Mundus moralis deals with the moral dimensions of man, it is discussed together with other political, politico-philosophical, or educational issues (Schifferová, 1993, pp. 50-64). Compared with other Comenian writings, as well as with other parts of the Consultation, Mundus moralis shows that it is in many ways an unfinished work, the final edition of which was never made. The work also lacks a uniform concept, much of it remains faintly, and the thought continuity is often unclear. Here we find a large variety of references and citations, often inaccurate, suggesting that Comenius gathered them to later clarify the relevant issues, and probably with the intention of making substantial reductions of or refinements to the text in the final processing (Schifferová, 1992, pp. 249-250). Nevertheless; despite its incompleteness, Comenius' Moral World provides good idea of Comenius' ethical thinking, especially of his conception of moral virtues that is our focus here.

The basic principles of the Moral World are contained in the first introductory chapter, Mundus Moralis quid, et quae illius Principia, where the author emphasizes that the moral foundation of the World lies in human nature. That remains the same in all people, and its basic requirement is that the person lives like a human, not as a dull beast (Comenius, 1966a, p. 549). ${ }^{7}$ Here it should be noted that this is a clear reference to natural law theory, which recognizes the standards of human nature as the supreme criterion for norm correctness. This would be nothing too special, since the tradition of natural law theory comes from ancient philosophers and was also recognized in various forms in the Middle Ages. However significant differences existed between the different variants of natural law theories, for the conviction of the close relation between nature and reason is typical of all of them. Generally, it can be said that natural law theory in all its forms presupposes a reasonable nature and its corresponding human mind, which is able to recognize this nature and to subtract from it the laws and rules of human conduct.

Nevertheless; the fact that Comenius based his Moral World on human nature is gaining importance, especially if we keep in mind that Comenius was a theologian of the Unity of Brethren. As such he was confronted with Protestant beliefs about the irreversible corruptness of human nature, which was the basic theological proposition of the reformist movement of the 16th century. ${ }^{8}$ The problem of the concept of human nature in Comenius' views on ethics deserves more thorough attention. It would be also interesting to indicate Comenius Mundus

\footnotetext{
${ }^{7}$ Mundi Moralis basis sit Naturae Humanae identitas seu aequalitas, hoc requirens, ut Omnes Homines vivant humaniter, non brute aut bestialiter.

${ }^{8}$ While the foundation of moral principles on human nature is not unusual, it was highly original that Comenius derived his teaching art from human nature, as pointed out by Stanislav Sousedík (Sousedík, 1983, pp. 34-47).
} 
moralis for understanding the context of the Protestant ethic, but that would far exceed the scope of this paper. ${ }^{9}$

The first chapter of the Moral World is concluded with a reflection on the moral principles as derived from metaphysical principles. This derivation is not satisfactorily drafted, it is incomplete, but from the text it follows that Comenius (like many of his contemporaries) did not realize the philosophical difficulty of this process. ${ }^{10}$ The second chapter is devoted to human prudence (prudentia), which is presented as the builder of the Moral World. Its structure is further divided into six parts, each of which refers to prudence, namely: I. Ethicaprudence to regulate oneself, II. Symbiotica - prudence to control oneself and another, III. Economica - prudence to manage others associated in a society, especially in the family, IV. Scholastica - prudence to manage schools, V. Politica - prudence to manage the community, VI. Basilica or monarchica - prudence to govern the kingdom. At first glance, it is evident, that prudence occupies a fundamental position in the entire system (no matter how flawed and incomplete). In the second chapter, which is wholly devoted to prudence, it is defined as the art of taking care of tranquillity using certain resources and using them appropriately (Comenius, 1966a, p. 550). Comenius further explains that the essence of moral prudence is in the use, imitation, and control of oneself and others. The origin of prudence is necessary, according to the author, to be found in our tendencies, patterns of nature, and in the Scripture. Comenius points out that natural innate concepts are often a highly reliable guide of practical wisdom - and then for ethics. Comenius further gives universal moral laws of prudence, which take the form of guidelines and recommendations relating to prudence.

The following chapters explain how to behave prudently to oneself, among people and against them, and in the family, towards youth and in the government of the community. The penultimate chapter discusses the moral perfection of the world in opposition to so called monsters and their shortcomings, which hinder the government over human nature and finally the tenth chapter is a celebration of God's governance of the moral world. These chapters mainly contain particular regulations, guidance or quotations relating to prudent conduct in certain situations, their logical connections, however, are unclear in many places due to the aforementioned incompleteness of the work.

While the status of prudence in Comenius' Moral World is crucial, we find it difficult to discover the references to the other cardinal virtues. For example, justice is mentioned in chapter IV on the prudence in managing oneself, along with others or in chapter II - The art of dealing with people - Symbiotic. Comenius at this point indicates that the connecting links in human relations are primarily concord (concordia), justice (justitia), and faith (fides). Concord is included here, as not offending or provoking anybody, justice, not deceiving each other, and finally faith because we should take care of what concerns us as well as others appropriately (Comenius, 1966a, p. 570). ${ }^{11}$ At the beginning of the following chapter, which deals with prudence in controlling others merged into the community, Comenius reiterates

\footnotetext{
${ }^{9}$ Attention should especially be paid in this context to the practical philosophy of Comenius' teacher Herborn Johann Heinrich Alsted (1588-1638), as presented in the IVth part of his Encyclopedia. At first glance, it is obvious that some parts of Alsted's ethics coincide with Comenius's Moral World chapters. In the introduction Alsted explains that human nature leads to love of virtue. (Homo natura duce amat honestum) Human nature has been corrupted by original sin, but may be, in Alsted's opinion, rectified by philosophy to some extent. Theoretical philosophy eliminates the disease of the mind, practical philosophy eliminates the disease of the will - vices (Alsted, 1630, p. 1236).

${ }^{10}$ The problem was formulated by David Hume, who pointed out that many authors conclude prescriptive sentences (ought to statements) based on descriptive sentences (is-statements). Called Hume's law or Hume's guillotine. (Hume, 1739, III, I, 1).

${ }_{11}$ Vinculum conversationis potissimum sunt Concordia, Justitia et Fides... Justita, ut alter alterum ne defraudemus...
} 
that relationships with other people requires humanity, justice and goodness, and other virtues which characterize friendly ties (Comenius, 1966a, p. 577). ${ }^{12}$ Brief mentions of justice are found even in the seventh chapter - Politics, where Comenius emphasizes the need for a just ordering of society and laws that are the standard for justice (Comenius, 1966a, p. 586). ${ }^{13}$ Temperance - temperantia is mentioned in the chapter on Ethics where Comenius also engaged it in self-control issues, in which he sees the essence of being temperate (Comenius, 1966a, p. 562). ${ }^{14}$ The same chapter also explains that temperance is needed for a person not to fall into unrestrained desires, such as unrestrained desire for wealth, pleasure, fame, or knowledge. Fortitude is cited as one of the desirable virtues in the event when it is necessary to face adversity, through equanimity, magnanimity and patience (Comenius, 1966a, p. $567) .^{15}$

It can be briefly summarized that Comenius's Mundus moralis is built on the fundamental role of prudence, while the other cardinal virtues are subordinated only to one of its species. Comenius did not adhere to the schema of four cardinal virtues; on the one hand, the above intentioned role of prudence suggests (as will be shown) a certain conformity with the traditional concept.

\section{The ancient concept of moral virtues - Aristotle}

Aristotle, on whose intellectual legacy this concept is largely based, developed his ethics clearly in terms of virtues. These are understood as a kind of soul quality, a habitus - a stable disposition that enables certain actions to be carried out easily. You could also say that through frequent repetition, one becomes more at ease with a certain activity and thereby acquires habit (Aristotle, 1103a 15-20). In the case of virtues in respect of morally good acting, it stands in the middle between two undesirable positions. Aristotle divided virtues into those improving reason and those perfecting the will and sensual assiduity. Various virtues are manifested in various areas of human life, among which Aristotle ranks fortitude and temperance (Aristotle, 1107a 28-1108b 10). Justice is discussed in considerable depth later in Book $\mathrm{V}$ of Nicomachean Ethics which begins with the claim that justice is the condition that renders us just agents inclined to desire and practise justice. Further, Aristotle specifies it in terms of what is lawful and fair. Two sorts of justice are further distinguished: distributive justice that involves dividing benefits and burdens fairly among members of a community, while corrective justice requires us, in some circumstances, to try to restore a fair balance in interpersonal relations where it has been lost. Like all moral virtues, for Aristotle, justice is a rational means between bad extremes. Proportional equality involves the "intermediate" position between someone unfairly getting "less" than is deserved and unfairly getting "more" at another's expense (Aristotle, 1129a-1132b, 1134a).

The last cardinal virtue is prudence; Aristotle ranked it among the intellectual virtues, along with knowledge, art, understanding and wisdom. ${ }^{16}$ The only one of them, which applies to human behaviour, is prudence. While Plato considered wisdom (sofia, sapientia) one of the foremost virtues, which is a virtue of the rulers in his Republic (Plato, 427 e), ${ }^{17}$ Aristotle replaced this virtue with prudence (phronésis, prudentia). ${ }^{18}$ In his conception it is a rational

\footnotetext{
12 Vidimus praecendenti capite, quomodo nemo nostrum nascatur sibi uni, ac necessitate conversandi ad Humanitatis, Justitiae, Benignitatis, aliarumque virtutum amicabilium exercitium devinciantur omnes.

${ }^{13}$ Leges sint norma justitiae, ideae rerum agendarum.

${ }^{14}$ Regimen suiipsius in cupiditatibus per Temperantiam.

${ }^{15}$ Fortitudine animi hic opus est, quae vincat omnia per aequanimitatem, magnanimitatem, patientiamque.

${ }^{16}$ The concept of Aristotle's phronésis is treated thoroughly by Aubenque (Aubenque, 1963).

${ }^{17}$ The concept is derived from the virtues of an ideal city-state, which are to be wise, courageous, sober and fair.

${ }^{18}$ Wisdom remains one of the intellectual virtues, in some respects superior to prudence, but prudence is directly related to human behaviour, while wisdom refers to divine things.
} 
sound judgment relating to human behaviour in terms of its accuracy. So it is a virtue that in this sense stands above the other virtues, because it governs them in accordance with intellectual knowledge so that they follow a good purpose. Although Aristotle was concerned with all the cardinal virtues, it should be noted that this quartet is not thematised in his work, cardinal virtues are treated separately and to gather them together into one unit is a mere interpretation.

The foursome of cardinal virtues; nevertheless; can be found in Cicero, particularly in the work De Officiis, where the four components of virtue are described, in which all honest behaviour is based (Cicero, 1994, I,5,15). It turns out, however, that in this text Cicero rather held Plato's teachings that systematically assigned the main place to the virtue of wisdom knowledge of things divine and human, rather than to prudence, which, as stated, is the knowledge of things desirable and contemptible. However, he also dealt with prudence and defined it as the knowledge of good, bad, and neutral things including memory (memoria), intelligence (intelligentia), and providence (providentia).

\section{Thomas Aquinas on cardinal virtues}

The four cardinal virtues, mainly based on Platonic Stoic tradition, enriched by some Biblical elements, were later adapted to a Christian context, primarily due to St. Ambrose, who was the first to use the term cardinal virtues. ${ }^{19}$ Since the Patristic writers it made a major impact on the Middle Ages especially in Jerome's concept of virtue and above all Augustine's ethics. His work includes two approaches to cardinal virtues. The first is relatively optimistic about the ability to achieve spiritual perfection. In the latter, Augustine was under the influence of the polemics with Pelagianism, and he held rather pessimistic views. In the City of God, he even rejected the possibility of the virtues of non-Christians, arguing that mastery over the body remains poor, if it is not formed by the spirit of true religion. This position is close to that of the Lutherans, for which human nature is so corrupt that it is naturally incapable of good deeds.

A lively medieval ethical debate followed especially on the part of these Church Fathers and ancient sources, and from the $13^{\text {th }}$ century, Aristotle's doctrine became an important source. The rediscovered Aristotelian ethics gave rise to new ethical considerations of many philosophers and theologians, from which the most important was Thomas Aquinas. Aquinas took the theme as a key issue in two of his works, in Questiones disputatae de virtutibus q. 5 and in the Summa of theology II, 1-2. To some extent, there he follows the doctrine of Augustine, which is nevertheless developed along the lines of Aristotelianism.

In his Questiones disputatae Aquinas (referring to Aristotle's doctrine) explains firstly that man is of sensuous nature, which also animals have. But what makes us human different from animals is reason and therefore it is necessary to seek a control element not in the plane of the senses (pleasure-centred), which is insufficient for human behaviour, but in the rational plane, which is thus decisive for humans. Reason, however, is twofold, partly speculative, and partly practical. Practical reason is the most appropriate for man because it is the principle of active life. Practical science is very important for life - everyone needs it, because everyone in this life acts, while speculation is not a standard, but rather a transcendent aspect of man.

The activity of a virtuous life is significantly influenced by the deliberation of what needs to be done, and prudence is a virtue that cultivates this rational thinking. For Aquinas it is the main virtue, because it should be said that the rational is the principal part of man. However, something is rational in two ways, essentially or by way of participation and, just as reason itself is more principal than the powers participating in reason, so prudence is more principal

\footnotetext{
19 The outline of development of the conception of cardinal virtues in ancient times and the Middle Ages is provided by Tomáš Machula (Machula, 2013, pp. 4-23).
} 
than the other virtues (Aquinas, 2013, q. 5, 1,11). ${ }^{20}$ Aquinas confirms the four cardinal virtues, "it should be said that the cardinal virtues are called more principal, not because they are more perfect than all the other virtues, but because human life more principally turns on them and the other virtues are based on them" (Aquinas, 2013, q. 5, 1, 12). ${ }^{21}$

Other virtues are derived from the cardinal as their integrating parts (partes integrantes), i.e. those that help to ensure that the virtue was complete, or perfect, or as their potential parts (partes potentiales), i.e. those which, although they agree in some way with the cardinal virtues, are somehow not implemented in the concept perfectly, and finally subjective parts (subjectivae partes) which are subject to cardinal virtues as a species to genus.

If we focus our attention on prudence that has, as already stated, the key role, we find that its integrating virtues are acts of reason, which is prepared for correct judgment. These include memory (memoria), providence (providentia) or vigilance (circumspectio) and caution (cautio). Its potential parts are eubulia - resourcefulness in providing advice, synesis - appropriate judgement according to the rules of the corresponding situation and gnomé -a higher judgment on things, in which it is sometimes necessary to derogate from the general law. Finally, the subjective parts of prudence are personal prudence, prudence in the management of others (family prudence - in the management of the family, political prudence - in the management of the state). In the same way it would be possible to determine the portion of the remaining three cardinal virtues.

\section{Conclusion}

Returning now to Comenius Moral World, it is clear that the concept of prudence largely corresponds to the Aristotelian notion of prudence (phronésis) as a virtue that belongs to human reason. Reason is typical of human nature; it is precisely the rational side which differentiates human nature from animal. In the traditional Aristotelian-Thomist schema prudence exists as a necessary condition of the other virtues, which controls action through the last practical judgment. On the other hand, as prudence has no sense without the other virtues, neither the other virtues are thinkable without prudence. If behaviour is not properly attached to virtues, reason is not inclined to judge correctly. This scheme, however, we do not find in Comenius' Moral World. However it emphasizes the priority of prudence and the resulting dependence of the other virtues, the fact that the other virtues are also necessary for prudence itself, Comenius' text does not show explicitly.

Comenius' own interpretation is directed along the lines of subjective subordinate parts (partes subjectivae) of prudence. According to them his Mundus moralis is divided into other chapters - prudence to themselves, to others in the family, in the kingdom, etc. In these chapters we find references to other cardinal virtues, which, nevertheless, are not given special attention. They stand beside other virtues without special emphasis on their status.

As is known, Comenius drew on many sources, both traditional and contemporary, reflected the philosophical and theological considerations and on this basis, he then built his original projects. It was pointed out that in the Moral World an ancient Socratic line is represented, resulting in stoicism, especially Seneca, Biblical tradition, namely the immediate effect of the Gospels and Paul of Tarsus and through a reformed Christianity (Schifferová, 1993, pp. 50-64). But I believe and I even tried to show, to give priority to, prudence

\footnotetext{
${ }^{20}$ Ad undecimum dicendum est, quod principalis pars hominis est pars racionalis. Sed rationale est duplex: scilicet per essentiam et per participationem; et sicut ipsa ratio est principalior quam vires participantes ratione, ita etiam prudentia est principalior quam aliae virtutes.

${ }^{21}$ Ad duodecimum dicendum, quod virtutes cardinales dicuntur principaliores omnibus aliis, non quia sunt omnibus aliis perfectiores, sed quia in eis principalius versatur humana vita, et super eas aliae virtutes fundantur.
} 
(prudentia), as the intellectual virtue which makes us human, it is one of the essential features of the Moral World, which refers to the Aristotelian or Thomist tradition.

Prudentia in Comenius plays a role in the final adjudicator of the moral conduct of man, thus becoming the rule of the other virtues. The emphasis on the rational judgment connects the Aristotelian tradition with early modern thinkers. Its validity, however, I believe, is timeless. Without adequate intellectual assessment, the content of individual virtues can easily be emptied. In some cases, the unilateral application of a virtue without intellectual insight, which will consider its appropriateness in the situation, leads to dangerous or pernicious consequences, which in recent times, unfortunately, we have often become witnesses to.

\section{Acknowledgement}

This study is a result of research funded by the Czech Science Foundation for project GA ČR 17-18261S - Political philosophy in the $17^{\text {th }}$ century Czech Lands.

Kateřina Šolcová works as an external fellow of the Department of Comenius Studies and Early Modern and Intellectual History of the Institute of Philosophy, Czech Academy of Sciences in Prague, where she works as an editor of Latin works in the critical edition J. A. Comenii Opera omnia. Her research field of interest is early modern thought with respect to the philosophical principles of Comenius' work.

\section{Corresponding author:}

Kateřina Šolcová, Filosofický ústav Akademie věd České republiky, The Institute of Philosophy, Czech Academy of Sciences, 11000 Prague 1, Jilská 1, Czech Republic

Email: solcova@flu.cac.cz

\section{References}

ALSTED, J. H. (1630): Encyclopaedia 14 : In Quo Philosophia Practica Quatuor hisce libris repraesentatur : I. Ethica. II. Oeconomica. III. Politica. IV. Scholastica. Herborn: Herbornae Nassoviorum.

AQUINAS, T. (2013): Questiones disputatae de virtutibus. Otázky o ctnostech III. Kardinální ctnosti [Questions on Virtues III: Cardinal Virtues], ed. and trans. T. Machula. Prague: Krystal OP.

ARISTOTLE (2009): The Nicomachean Ethics, trans. D. Ross, ed. L. Brown. Oxford: Oxford University Press.

AUBENQUE, P. (1963): La Prudence Chez Aristote. Paris: Presses Universitaires de France. CICERO (1994): De officiis, ed. M. Winterbottom. Oxford: Oxford University Press.

COMENIUS, J. A. (1966a): Mundus moralis. In: J. A. Comenius: De rerum humanarum emendatione consultatio catholica I. Prague: Academia, pp. 543-597.

COMENIUS, J. A. (1966b): Lexicon reale pansophicum. In: J. A. Comeniuss: De rerum humanarum emendatione consultatio catholica II. Prague: Academia, pp. 441-681.

HUME, D. (1739): A Treatise of Human Nature: Being an Attempt to introduce the experimental Method of Reasoning into Moral Subjects. London: John Noon.

MACHULA, T. (2013): Tomáš o kardinálních ctnostech [Aquinas on Cardinal Virtues]. In: T. Aquinas: Questiones disputatae de virtutibus. Otázky o ctnostech III. Kardinální ctnosti, ed. and trans. T. Machula. Prague: Krystal OP, pp. 3-23.

PLATO (2008): Republic, ed. and trans. R. Waterfield. Oxford: Oxford University Press.

SCHIFFEROVÁ, V. (1992): Pansofia - Svět mravní - Komentář [Pansophy - Moral World Commentary]. In: J. A. Comenius: Obecná porada o nápravě věci lidských II [General Consultation on an Improvement of All Things Human II]. Prague: Svoboda, pp. 249-263. 
SCHIFFEROVÁ, V. (1993): Komenského Mundus moralis [Comenius' Moral World]. In: I. Šnebergová (ed.): Po cestách naléhavosti myšlení [The Ways of Thought Urgency]. Prague: Filosofia, pp. 50-64.

SOUSEDÍK, S. (1983): Comenius' Prinzip der Natürlichkeit der Erziehug. In: Theologie und Philosophie, 58, pp. 34-47. 